\title{
MARINE RADIOCARBON RESERVOIR EFFECT OF COASTAL WATERS OFF CAPE VERDE ARCHIPELAGO
}

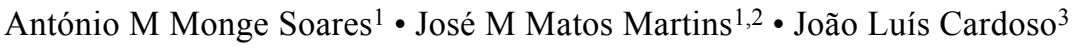 \\ ABSTRACT. Quantification of the marine radiocarbon reservoir effect $(\Delta \mathrm{R})$ is essential in order to calibrate conventional \\ ${ }^{14} \mathrm{C}$ dates from marine shell samples with reliability. $\Delta \mathrm{R}$ also provides information concerning the intensity of coastal \\ upwelling in marine regions influenced by this phenomenon. ${ }^{14} \mathrm{C}$ ages of closely associated marine samples (mollusk shells) \\ and terrestrial samples (goat bones) from São Vicente Island, Cape Verde Archipelago, permitted the first calculation of the \\ marine ${ }^{14} \mathrm{C}$ reservoir effect in this region. $\mathrm{A} \Delta \mathrm{R}$ weighted mean value of $70 \pm 70{ }^{14} \mathrm{C}$ yr was obtained. This value is in accor- \\ dance with the previously published oceanographic conditions of the region indicating the existence of a seasonal active \\ upwelling regime.
}

\section{INTRODUCTION}

Radiocarbon dates on marine shells have not been used as extensively as charcoal or bone dates for the construction of absolute chronologies because interpreting these dates is complicated by oceanographic factors. Nevertheless, marine shellfish were widely used by prehistoric societies in various locations throughout prehistory and their shells are abundant and usually well preserved in archaeological deposits. Previous research concerning oceanographic conditions and an accurate quantification of the marine ${ }^{14} \mathrm{C}$ reservoir effect of a particular coastal area are needed in order to build reliable regional chronologies using ${ }^{14} \mathrm{C}$-dated marine shell samples.

Some years ago, one of us ( $\mathrm{J}$ L Cardoso) supervised an archaeological excavation carried out in a small settlement site located on São Vicente Island (Cape Verde Archipelago), composed of dry stone walls of European style but with a remarkable accumulation of shells - a true shell middenand abundant fragments of handmade ceramics. This settlement contains perhaps the oldest remains of human origin on São Vicente Island and consequently it was of paramount importance to get reliable and accurate ${ }^{14} \mathrm{C}$ dates for those archaeological contexts (Cardoso et al. 2003/2004). Thus, an opportunity arose for the quantification of the marine ${ }^{14} \mathrm{C}$ reservoir effect of coastal waters off that archipelago, which is located in a region where this kind of research has been uncommon.

\section{OCEANOGRAPHIC CONDITIONS OFF CAPE VERDE ARCHIPELAGO}

The Cape Verde Islands are located in the North Atlantic Ocean between latitude $14^{\circ} 23^{\prime} \mathrm{N}$ and $17^{\circ} 12^{\prime} \mathrm{N}$ and longitude $22^{\circ} 40^{\prime} \mathrm{W}$ and $25^{\circ} 22^{\prime} \mathrm{W}$. The archipelago includes 10 islands of volcanic origin, divided into the Barlavento (windward) and Sotavento (leeward) groups (Figure 1). The dominant current in Cape Verde coastal waters (Figure 2) is the North Equatorial Current (NEC), which is considered the southern boundary of the North Atlantic subtropical gyre (Vangriesheim et al. 2003). This current results from 4 major factors: 1) the Canary Current (CC); 2) the shape and bathymetry of the African continental shelf; 3) the tradewinds; and 4) the position of the Cape Verde frontal zone (Machín et al. 2006). Due to the combination of these factors, the Canary Current flows west and separates from the African coast, reaching the Cape Verde frontal zone where the NEC is formed (Machín et al. 2006; Pelegrí et al. 2006).

\footnotetext{
${ }^{1}$ Laboratório de Radiocarbono, Grupo de Química Analítica e Ambiental, Instituto Tecnológico e Nuclear, Estrada Nacional 10, 2686-953 Sacavém, Portugal. Corresponding author. Email: amsoares@itn.pt.

${ }^{2}$ Universidade do Algarve, Faculdade de Ciências e Tecnologia (Campus de Gambelas, Faro), Portugal.

${ }^{3}$ Universidade Aberta (Lisboa), Centro de Estudos Arqueológicos do Concelho de Oeiras, Câmara Municipal de Oeiras, Fábrica da Pólvora de Barcarena, Estrada das Fontainhas, 2745-615 Barcarena, Portugal.
} 


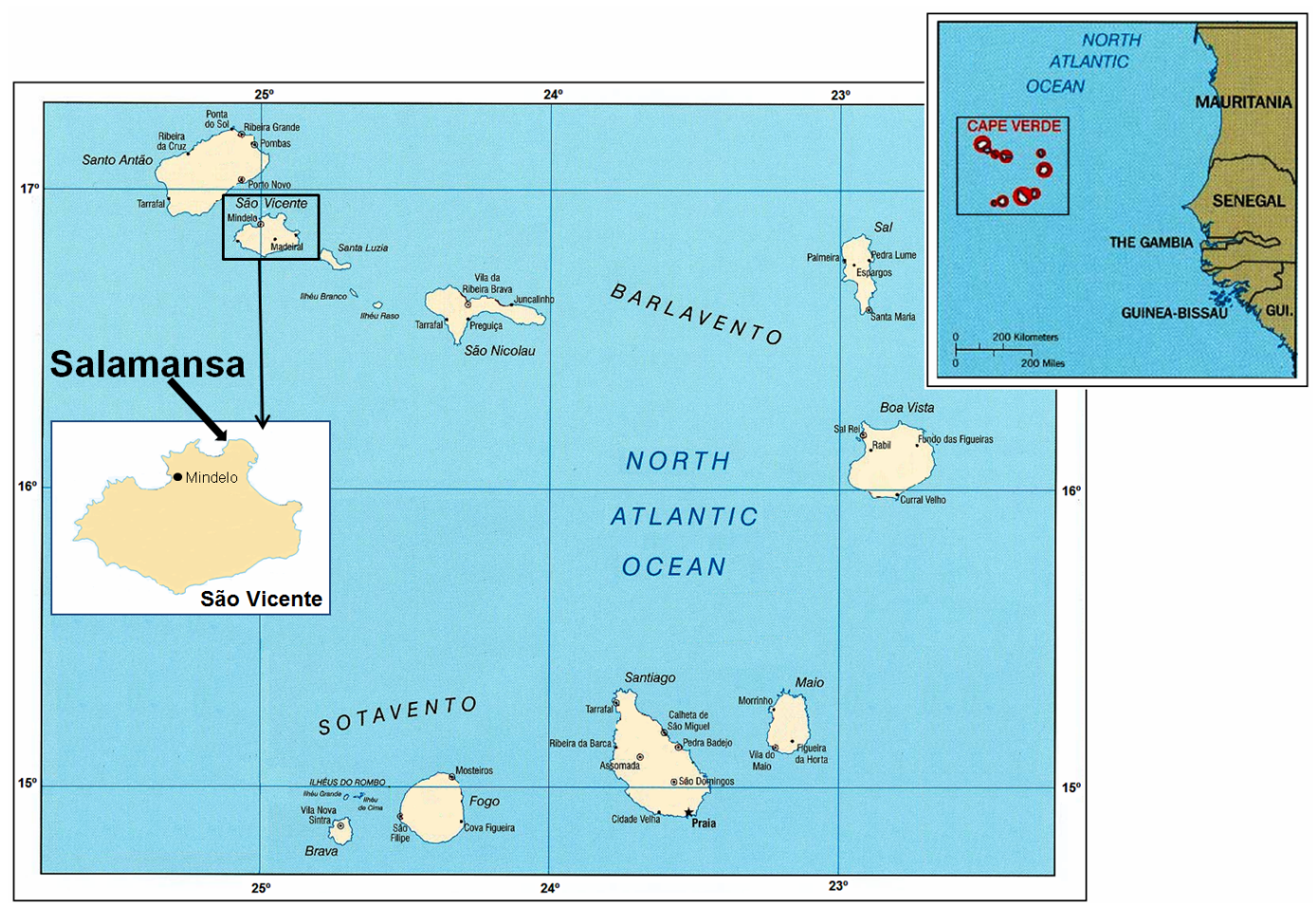

Figure 1 Location of Cape Verde Archipelago. The sampled archaeological site (Salamansa) is situated on São Vicente Island.

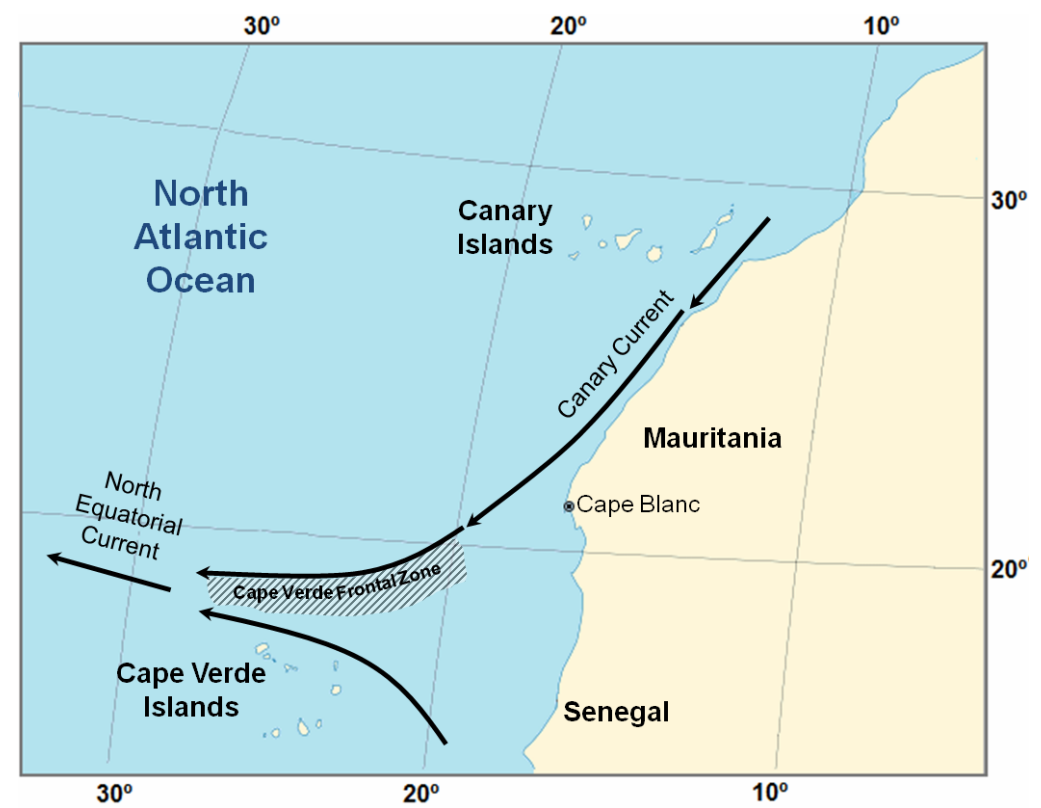

Figure 2 Schematic of upper ocean currents in the northeast Atlantic subtropical area off the African coast, following Spall (1992) and Vangriesheim et al. (2003). 
The Cape Verde frontal zone is located between $15^{\circ} \mathrm{N}$ and $25^{\circ} \mathrm{N}$ and corresponds to the eastern portion of the water mass boundary between the North Atlantic Central Water (NACW) and the South Atlantic Central Water (SACW) (following Zenk at al. 1991). This frontal zone is characterized by its instability and mesoscale variability, which separates and merges the 2 water masses (Spall 1992; Pérez-Rodríguez et al. 2001; Vangriesheim et al. 2003). The NACW (salty, nutrient-poor, and oxygen-rich) has its source in the high latitudes of the North Atlantic Ocean, reaching lower latitudes due to thermohaline circulation. On the other hand, the SACW (fresh, cold, nutrient-rich, and oxygen-poor) originates in the sub-Antarctic region of the Southern Atlantic Ocean, reaching tropical regions as a result of thermohaline circulation. The interweaving of the NACW and SACW in the Cape Verde frontal zone can partially originate from the mesoscale feature of coastal upwelling in the region (Pastor et al. 2008).

The presence of upwelling filaments is common in the NW African coast, including the Cape Blanc upwelling filament, whose presence can be explained due to the interaction between the $\mathrm{CC}$ and the morphology of the African continental shelf. During winter and early spring, the upwelling filament stretches south beyond Cape Blanc, reaching Cape Verde coastal waters. The stretch of this upwelling filament to Cape Verde coastal waters can be explained by the fact that in winter and early spring, the convergence at the Cape Verde front is reduced, contrary to what occurs during summer, allowing the upwelling filament to reach the Cape Verde Archipelago (Pelegrí et al. 2006).

The southward extension of the northeast tradewinds also induces upwelling in Cape Verde coastal waters (Nykjaer and Van Camp 1994). The northeast tradewinds bring upwelled waters from the NACW across Cape Blanc, resulting in a winter band of high coastal upwelling that extends to the Cape Verde Islands (Pelegrí et al. 2006).

\section{$\mathrm{R}(\mathrm{t})$ AND $\Delta \mathrm{R}$}

The residence time of carbon in the deep ocean is about $1000 \mathrm{yr}$ (Sigman and Boyle 2000). Thus, a fraction of the ${ }^{14} \mathrm{C}$ atoms have time to decay (half-life $=5730 \mathrm{yr}$ ) while the deep water is out of contact with the atmosphere. The deep ocean is therefore depleted in ${ }^{14} \mathrm{C}$ relative to the atmosphere, and the surface seawater (mixed layer) also has a ${ }^{14} \mathrm{C}$ specific activity lower than that of the atmosphere but greater than that of the deep ocean. Consequently, a ${ }^{14} \mathrm{C}$ reservoir age exists for the ocean, i.e. an offset in ${ }^{14} \mathrm{C}$ age exists between coeval samples containing marine carbon versus those containing terrestrial carbon. Following Stuiver et al. (1986), the reservoir age, $\mathrm{R}(\mathrm{t})$, can be defined as the difference between conventional ${ }^{14} \mathrm{C}$ dates from a pair of coeval samples that lived in different carbon reservoirs (marine and terrestrial biosphere). $\mathrm{R}(\mathrm{t})$ is time-dependent due to variations of ${ }^{14} \mathrm{C}$ content in the atmosphere and differences between transfer rates of ${ }^{14} \mathrm{C}$ between the atmosphere and the ocean reservoir through time. Reservoir age is also variable from region to region in the ocean (Stuiver et al. 1986; Stuiver and Braziunas 1993; Reimer et al. 2002; Reimer and Reimer 2006) since the oceanographic conditions present in each region are different due to variations in reservoir parameters such as water mass mixtures, wind regimes, bathymetry, and upwelling of deep water.

Considering these issues, Stuiver et al. (1986) modeled the response of the world ocean to atmospheric ${ }^{14} \mathrm{C}$ variations. From this modeling, 2 calibration curves for marine samples have been derived: one related to the deep ocean and the other to the sea surface water (mixed layer), with Marine09 the most current curve (Reimer et al. 2009). However, in order to take into account the difference in ${ }^{14} \mathrm{C}$ content between the surface water of a specific region and the average surface water, a parameter, denoted as $\Delta \mathrm{R}$ (regional marine ${ }^{14} \mathrm{C}$ reservoir effect), is defined as the difference between the reservoir age of the mixed layer of the regional ocean and the reservoir age of the mixed layer of the average world ocean in AD 1950 (Stuiver et al. 1986). $\Delta \mathrm{R}$ values are often determined 
for a particular geographical region by ${ }^{14} \mathrm{C}$ dating of pairs of samples of the same age but of different origin (terrestrial and marine) and converting the terrestrial biosphere sample ${ }^{14} \mathrm{C}$ age into a marine model age; this marine model age is then deducted from the ${ }^{14} \mathrm{C}$ age of the associated marine sample to yield $\Delta \mathrm{R}$ (Stuiver and Braziunas 1993). Although reservoir ages are time-dependent, $\Delta \mathrm{R}$ is not unless some change of oceanographic conditions restricted to the considered regional ocean has occurred. This happens, for instance, in regions affected by the upwelling of deep water. Since rates of regional upwelling can vary in the course of time, and the intensity of the ${ }^{14} \mathrm{C}$ depletion in the mixed layer depends upon the strength of wind-driven coastal upwelling, it is likely that $\Delta \mathrm{R}$ values can also vary in the course of time (Kennett et al. 1997; Ingram 1998; Ascough et al. 2005; Soares 2005; Soares and Dias 2006, 2007). Positive high $\Delta \mathrm{R}$ values can be correlated with a strong upwelling, while low or negative $\Delta \mathrm{R}$ values correspond with a weak, or even nonexistent, upwelling. As a measure of the regional enhancement or depletion of ${ }^{14} \mathrm{C}, \Delta \mathrm{R}$ can also be used as an upwelling proxy, providing the most direct signal of upwelling activity (Diffenbaugh et al. 2003).

The NW African coastal upwelling system is characterized, as mentioned above, by a complex and heterogeneous oceanographic pattern that extends south to Cape Verde in winter and north to the Iberian Peninsula in summer (Wooster et al. 1976; Láiz et al. 2000; Pelegrí et al. 2006). Some studies concerning the marine ${ }^{14} \mathrm{C}$ reservoir effect for this area have been done, namely for the i) Iberian Atlantic coast (Soares 1993, 2005, 2010; Soares and Dias 2006, 2007; Soares and Martins 2009, 2010); ii) Canary Islands (Soares et al. 2009); and iii) Mauritania and Senegal (Ndeye 2008). This paper focuses in a coastal area (Cape Verde Archipelago) within this upwelling system not yet examined in previous studies concerning the marine ${ }^{14} \mathrm{C}$ reservoir effect.

\section{SAMPLING}

Pairs of closely associated archaeological samples (marine shells/goat bones) were collected from Salamansa archaeological site (Figure 3). Each pair resulted from kitchen refuse, collected in close stratigraphic proximity from a section of the midden with good stratigraphic definition. It is assumed that the deposition of both kinds of samples (terrestrial and marine) was simultaneous (i.e. that the time of death of the organisms, from both reservoirs, was the same). Besides those pairs, other samples of bones or shells were collected for ${ }^{14} \mathrm{C}$ dating from the same level of the pair (i.e. Salamansa QA Am2 was collected at the same level of Salamansa QA Am1, but at a different location) or from different levels (see Table 1) in order to get not only a reliable chronology for the Salamansa archaeological remains, but also to test the reliability of the ${ }^{14} \mathrm{C}$ dates determined with the sample pairs.

\section{EXPERIMENTAL}

Samples were first cleaned by manually removing foreign material. For bone samples (only with a $\mathrm{N}$ content higher than $1 \%$ measured with an Elemental Analyzer 1110, CE Instruments), gelatin was extracted using the Longin (1970) method. Marine shell samples were usually restricted to whole valves of the same species with no visual evidence of surface deterioration. Nevertheless, the outermost $30 \%$ by weight, at least, of the shells was discarded by controlled acid leaching $(0.5 \mathrm{M} \mathrm{HCl}$ at $25^{\circ} \mathrm{C}$ ). For the Salamansa QA Am1 sample, a controlled acid hydrolysis was used to separate approximately equally sized volumes of $\mathrm{CO}_{2}$ representative of the intermediate fraction and the inner fraction of the shells carbonate structure, in order to be ${ }^{14} \mathrm{C}$ dated.

The ${ }^{14} \mathrm{C}$ content was measured by means of the liquid scintillation technique described elsewhere (Soares 1989, 2005). All samples were converted to benzene and ${ }^{14} \mathrm{C}$ content was measured in a Packard Tri-Carb 2770TR/SL spectrometer. Stable isotope enrichment values $\left(\delta^{13} \mathrm{C}\right)$ were deter- 

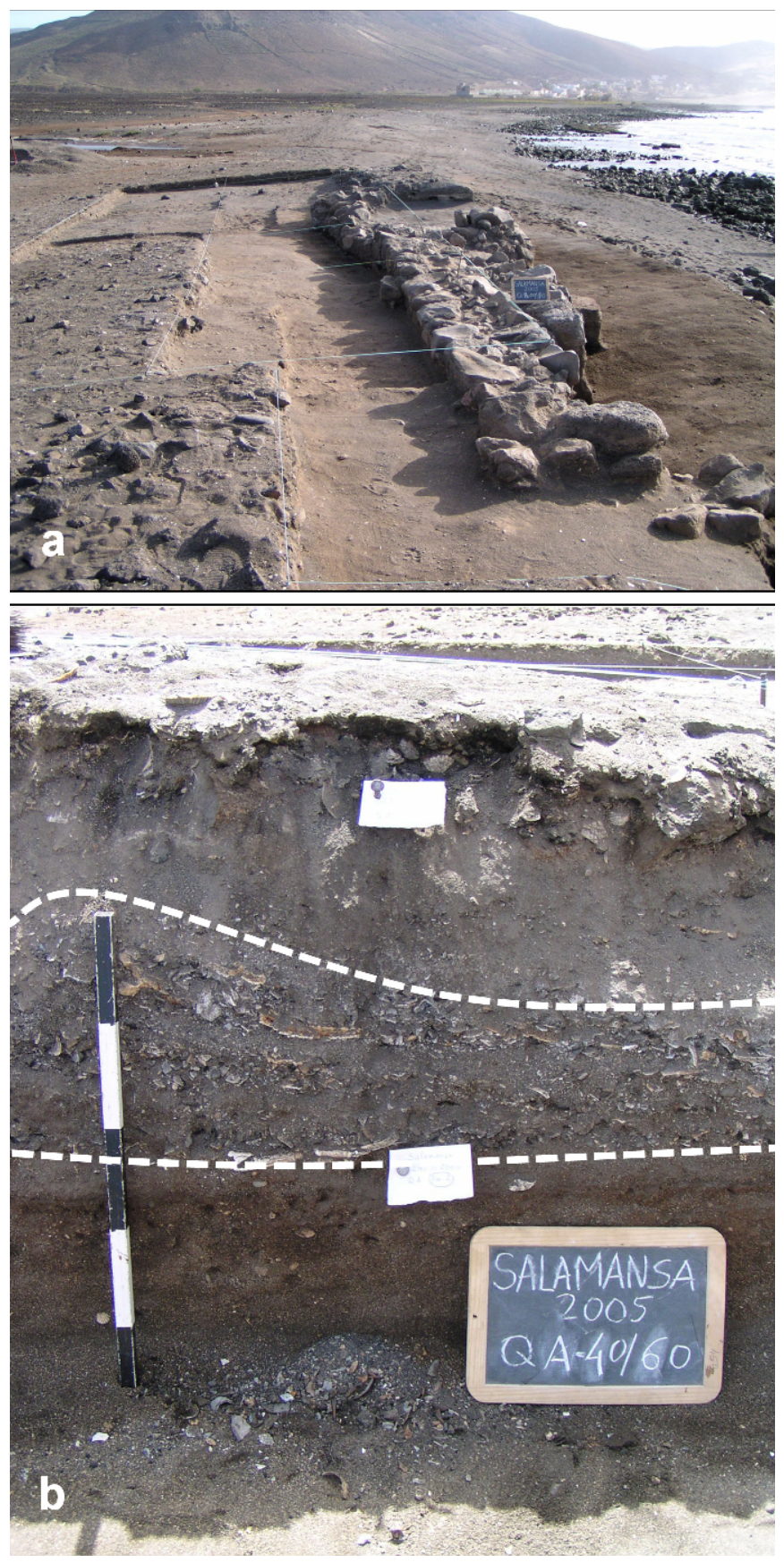

Figure 3 Archaeological excavation at the settlement site of Salamansa: a) overview of the archaeological site; $b$ ) stratigraphic profile of the section from which the samples Salamansa QA Am1 and QA Am2 were collected. Organic remains (goat bones, marine shells, turtle carapaces and plastrons, charcoal) between the 2 dashed lines (photos courtesy J L Cardoso). 
mined for the $\mathrm{CO}_{2}$ gas produced at the initial stage of benzene synthesis using a SIRA 10 (VG ISOGAS) isotope ratio mass spectrometer with dual inlet. ${ }^{14} \mathrm{C}$ ages were calculated in accordance with the definitions recommended by Stuiver and Polach (1977).

\section{RESULTS AND DICUSSION}

The ${ }^{14} \mathrm{C}$ age and $\delta^{13} \mathrm{C}$ of samples from the Salamansa archaeological site are listed in Table 1 . The first 4 samples were previously presented by Cardoso et al. (2003/2004), when preliminary results of the archaeological excavation were published. The $\delta^{13} \mathrm{C}$ of the bone samples show an enrichment that may result from the animal (goat) feeding habits, essentially plants, in this case tropical plants $\left(\mathrm{C}_{4}\right.$ plants) having a $\delta^{13} \mathrm{C}$ content between -17 and $-9 \%$ (Coleman and Fry 1991).

Table $1{ }^{14} \mathrm{C}$ age of samples from Salamansa archaeological site (São Vicente Island, Cape Verde).

\begin{tabular}{lllcl}
\hline Lab nr & Sample reference & Species & $\delta^{13} \mathrm{C}(\%)$ & ${ }^{14} \mathrm{C}$ age $(\mathrm{BP})$ \\
\hline Sac-1616 & Salamansa C1 & Capra hircus & -13.13 & $275 \pm 60$ \\
Sac-1528 & Salamansa C1 P & Patella spp. & -4.63 & $860 \pm 40$ \\
Sac-1530 & Salamansa C2 P & Patella spp. & 0 & $730 \pm 35$ \\
Sac-1531 & Salamansa C6 P & Patella spp. & +3.10 & $830 \pm 35$ \\
Sac-2167 & Salamansa QA Am1 & Capra hircus & -11.91 & $130 \pm 40$ \\
Sac-2132 & Salamansa QA Am1 P1 & Patella spp. ${ }^{\text {a }}$ & +3.42 & $530 \pm 35$ \\
Sac-2133 & Salamansa QA Am1 P2 & Patella spp. & +3.39 & $570 \pm 35$ \\
Sac-2165 & Salamansa QA Am2 & Capra hircus & -7.34 & $140 \pm 50$ \\
Sac-2166 & Salamansa G20/40 & Capra hircus & -10.59 & $150 \pm 35$ \\
\hline
\end{tabular}

antermediate fraction.

Two pairs of ${ }^{14} \mathrm{C}$ ages of closely associated samples (Sac-1616/Sac-1528 and Sac-2167/Sac-2133) were used to determine the marine ${ }^{14} \mathrm{C}$ reservoir effect $(\Delta \mathrm{R})$ and the reservoir age, $\mathrm{R}(\mathrm{t})$. Sac-2132, determined for the intermediate fraction of the sample Salamansa QA Am1, is merely an index of reliability for the inner fraction $\mathrm{Sac}-2133$ as are the inner and the intermediate fraction $\delta^{13} \mathrm{C}$ values.

Following Stuiver and Braziunas (1993) and Reimer et al. (2002), $\Delta \mathrm{R}$ values were calculated by converting the terrestrial sample ${ }^{14} \mathrm{C}$ age into a marine model age using the IntCal09 atmospheric calibration data set (Reimer et al. 2009). Subsequently, through the interpolation of the obtained calibrated interval $(1 \sigma)$ in the Marine09 calibration data set (Reimer et al. 2009), the marine model ${ }^{14} \mathrm{C}$ age $\pm 1 \sigma$ is determined. This marine model age was then subtracted from the ${ }^{14} \mathrm{C}$ age of the associated marine shell sample to yield $\Delta \mathrm{R}$. The $1-\sigma$ error for the $\Delta \mathrm{R}$ determination is obtained by propagation of the errors on the marine age and the modeled marine age.

$\mathrm{R}(\mathrm{t})$ values were also calculated following the definition of Stuiver et al. (1986) as mentioned above. The resulting $\Delta R$ and $R(t)$ values are listed in Table 2 . A $\Delta R$ weighted mean value of $70 \pm 70{ }^{14} \mathrm{C}$ yr was obtained. This value is in accordance with the dominant oceanographic conditions present in the area, which makes up the southern boundary of the NW African coastal upwelling region. As mentioned previously, positive high $\Delta \mathrm{R}$ values can be correlated with a strong upwelling. Similar values were achieved for coastal areas near Cape Verde Archipelago, namely in northern Senegal $(\Delta \mathrm{R}=$ $176 \pm 15{ }^{14} \mathrm{C}$ yr) and Mauritania $\left(\Delta \mathrm{R}=71 \pm 13{ }^{14} \mathrm{C}\right.$ yr) (Ndeye 2008). 
Table 2 Marine radiocarbon reservoir effect values for coastal waters off Cape Verde Archipelago.

\begin{tabular}{|c|c|c|c|c|c|c|c|c|}
\hline Lab nr & $\begin{array}{l}\text { Shell } \\
\text { sample } \\
\text { species }\end{array}$ & $\begin{array}{l}\delta^{13} \mathrm{C} \\
(\%)\end{array}$ & $\begin{array}{l}{ }^{14} \mathrm{C} \text { age } \\
(\mathrm{yr} \mathrm{BP})\end{array}$ & Lab nr & $\begin{array}{l}\text { Terrestrial } \\
\text { sample } \\
\text { species }\end{array}$ & $\begin{array}{l}\delta^{13} \mathrm{C} \\
(\%)\end{array}$ & $\begin{array}{l}{ }^{14} \mathrm{C} \text { age } \\
(\mathrm{yr} \mathrm{BP})\end{array}$ & $\begin{array}{l}\text { Model marine } \\
{ }^{14} \mathrm{C} \text { age } \\
(\mathrm{yr} \mathrm{BP})\end{array}$ \\
\hline Sac-1528 & $\begin{array}{c}\text { Patella spp. } \\
\Delta \mathbf{R}=\mathbf{1 9 0} \pm \mathbf{1 3 3}\end{array}$ & $\begin{array}{c}-4.63 \\
{ }^{14} \mathbf{C ~ y r}\end{array}$ & $860 \pm 40$ & Sac-1616 & $\begin{array}{l}\text { Capra hircus } \\
\mathbf{R}(\mathbf{t})=\mathbf{5 8 5} \pm \mathbf{7 6}\end{array}$ & $\begin{array}{r}-13.13 \\
\mathbf{0}^{14} \mathbf{C} \mathbf{~ y r} \\
\end{array}$ & $275 \pm 60$ & $670 \pm 127$ \\
\hline $\begin{array}{l}\text { Sac-2132a } \\
\text { Sac-2133 }\end{array}$ & $\begin{array}{c}\text { Patella spp. } \\
\text { Patella spp. } \\
\Delta \mathbf{R}=\mathbf{2 6} \pm \mathbf{8 3}\end{array}$ & $\begin{array}{r}3.42 \\
3.39 \\
{ }^{14} \mathbf{C ~ y r} \\
\end{array}$ & $\begin{array}{l}530 \pm 35 \\
570 \pm 35\end{array}$ & Sac-2167 & $\begin{array}{l}\text { Capra hircus } \\
\mathbf{R}(\mathbf{t})=\mathbf{4 4 0} \pm \mathbf{5 0}\end{array}$ & $\begin{array}{r}-11.91 \\
\mathbf{0}^{\mathbf{1 4}} \mathbf{C} \mathbf{~ y r} \\
\end{array}$ & $130 \pm 40$ & $544 \pm 75$ \\
\hline
\end{tabular}

${ }^{a}$ Intermediate fraction (not considered in the calculation of $\Delta \mathrm{R}$ and $\mathrm{R}(\mathrm{t})$ ).

\section{CONCLUSIONS}

A record of past reservoir ages is preserved in the ${ }^{14} \mathrm{C}$ ages of contemporary marine and terrestrial material. Thus, a $\Delta \mathrm{R}$ weighted mean value of $70 \pm 70{ }^{14} \mathrm{C}$ yr was determined for the coastal waters off Cape Verde Archipelago. This value must be used in association with the marine calibration curve (Marine09) in order to get accurate calendar dates from marine shell samples collected in the Cape Verde Archipelago region. Nevertheless, further research using more pairs of samples from Sotavento and Barlavento islands is needed, in order that the temporal and spatial variability of the marine ${ }^{14} \mathrm{C}$ reservoir effect in this North Atlantic region can be more reliably measured.

\section{ACKNOWLEDGMENTS}

J Martins acknowledges the PhD grant SFRH/BD/45528/2008 from Fundação para a Ciência e Tecnologia.

\section{REFERENCES}

Ascough P, Cook G, Dugmore A. 2005. Methodological approaches to determining the marine radiocarbon reservoir effect. Progress in Physical Geography 29(4):532-47.

Cardoso JL, Soares AMM, Reiner F, Guerreiro A, Barradas C, Costa R, Carvalho C. 2003/2004. O concheiro de Salamansa (ilha de São Vicente, arquipélago de Cabo Verde): nota preliminar. Portugalia Nova Série 23:221-31. In Portuguese.

Coleman DC, Fry B. 1991. Carbon Isotope Techniques. San Diego: Academic Press, Inc.

Diffenbaugh NS, Sloan LC, Snyder MA. 2003. Orbital suppression of wind-driven upwelling in the California Current at 6 ka. Paleoceanography 18:1051, doi: 10.1029/2002PA000865.

Ingram BL. 1998. Differences in radiocarbon age between shell and charcoal from a Holocene shellmound in northern California. Quaternary Research 49(1): $102-10$.

Kennett DJ, Ingram BL, Erlandson JM, Walker P. 1997. Evidence for temporal fluctuations in marine radiocarbon reservoir ages in the Santa Barbara Channel, southern California. Journal of Archaeological Science 24(11):1051-9.

Láiz I, Sangrà P, Pelegrí JL. 2000. Variabilidad estacional del borde oriental del Giro Subtropical del Atlántico
Norte. $3^{\circ}$ Simpósio sobre a Margem Ibérica Atlântica. p 159-60. In Spanish.

Longin R. 1970. Extraction du collagene des os fossils pour leur datation par la methode du Carbone 14 [these $3^{\mathrm{e}}$ cycle]. Lyon: Faculté des Sciences de l'Université de Lyon. In French.

Machín F, Hernández-Guerra A, Pelegrí JL. 2006. Mass fluxes in the Canary Basin. Progress in Oceanography 70(2-4):416-47.

Ndeye M. 2008. Marine reservoir ages in northern Senegal and Mauritania coastal waters. Radiocarbon 50(2):281-8.

Nykjaer L, Van Camp L. 1994. Seasonal and interannual variability of coastal upwelling along northwest Africa and Portugal from 1981 to 1991. Journal of Geophysical Research 99(C7):14,197-207.

Pastor MV, Pelegrí JL, Hernández-Guerra A, Fonta J, Salata J, Emelianova M. 2008. Water and nutrient fluxes off northwest Africa. Continental Shelf Research 28(7):915-36.

Pelegrí JL, Marrero-Díaz A, Ratsimandresy AW. 2006. Nutrient irrigation of the North Atlantic. Progress in Oceanography 70(2-4):366-406.

Pérez-Rodríguez P, Pelegrí JL, Marrero-Díaz A. 2001. Dynamical characteristics of the Cape Verde frontal zone. Scientia Marina 65(S1):241-50. 
Reimer RW, Reimer PJ. 2006. Marine reservoir corrections and the calibration curve. PAGES News 14(3): $12-3$.

Reimer PJ, McCormac G, Moore J, McCormick F, Murray EV. 2002. Marine radiocarbon reservoir corrections for the mid- to late Holocene in the eastern subpolar North Atlantic. The Holocene 12(2):129-35.

Reimer PJ, Baillie MGL, Bard E, Bayliss A, Beck JW, Blackwell PG, Bronk Ramsey C, Buck CE, Burr GS, Edwards RL, Friedrich M, Grootes PM, Guilderson TP, Hajdas I, Heaton TJ, Hogg AG, Hughen KA, Kaiser KF, Kromer B, McCormac FG, Manning SW, Reimer RW, Richards DA, Southon JR, Talamo S, Turney CSM, van der Plicht J, Weyhenmeyer CE. 2009. IntCa109 and Marine09 radiocarbon age calibration curves, 0-50,000 years cal BP. Radiocarbon 51(4): 1111-50.

Sigman DM, Boyle EA. 2000. Glacial/interglacial variations in atmospheric carbon dioxide. Nature 407(6806):859-69.

Soares AMM. 1989. O Efeito de Reservatório Oceânico nas Águas Costeiras de Portugal Continental. Sacavém: Instituto de Ciências e Engenharia Nucleares (Instituto Nacional de Engenharia e Tecnologia Industrial). 135 p. In Portuguese.

Soares AMM. 1993. The ${ }^{14} \mathrm{C}$ content of marine shells: evidence for variability in coastal upwelling off Portugal during the Holocene. In: Isotope Techniques in the Study of Past and Current Environmental Changes in the Hydrosphere and the Atmosphere. Vienna: International Atomic Energy Agency (IAEA). p 471-85.

Soares AMM. 2005. Variabilidade do "Upwelling” Costeiro durante o Holocénico nas Margens Atlânticas Ocidental e Meridional da Península Ibérica $[\mathrm{PhD}$ dissertation]. Faro: Faculdade de Ciências do Mar e do Ambiente, Universidade do Algarve. In Portuguese.

Soares AMM. 2010. Comment on "Formation of chenier plain of the Doñana marshland (SW Spain): observations and geomorphic model" by A. RodríguezRamírez and C.M. Yáñez-Camacho [Marine Geology 254 (2008) 187-196]. Marine Geology 275(1-4): 287-9.
Soares AMM, Dias JMA. 2006. Coastal upwelling and radiocarbon-evidence for temporal fluctuations in ocean reservoir effect off Portugal during the Holocene. Radiocarbon 48(1):45-60.

Soares AMM, Dias JMA. 2007. Reservoir effect of coastal waters off western and northwestern Galicia. Radiocarbon 49(2):925-36.

Soares AMM, Martins JMM. 2009. Radiocarbon dating of marine shell samples. The marine radiocarbon reservoir effect of coastal waters off Atlantic Iberia during Late Neolithic and Chalcolithic periods. Journal of Archaeological Science 36(12):2875-81.

Soares AMM, Martins JMM. 2010. Radiocarbon dating of marine samples from Gulf of Cadiz: the reservoir effect. Quaternary International 221(1-2):9-12.

Soares AMM, Mederos Martín A, Martins JMM. 2009. Radiocarbon dating of marine shell samples. The marine reservoir effect in Canary Islands coastal waters. Libro de Resúmes, VIII Congreso Ibérico de Arqueometría (Teruel, 19-21 October 2009). p 72.

Spall MA. 1992. Rossby wave radiation in the Cape Verde frontal zone. Journal of Physical Oceanography 22(7):796-807.

Stuiver M, Braziunas TF. 1993. Modeling atmospheric ${ }^{14} \mathrm{C}$ influences and ${ }^{14} \mathrm{C}$ ages of marine samples to 10,000 BC. Radiocarbon 35(1):137-89.

Stuiver M, Polach HA. 1977. Discussion: reporting of ${ }^{14}$ C data. Radiocarbon 19(3):355-63.

Stuiver M, Pearson GW, Braziunas T. 1986. Radiocarbon age calibration of marine samples back to $9000 \mathrm{cal} \mathrm{yr}$ BP. Radiocarbon 28(2B):980-1021.

Vangriesheim A, Bournot-Marec C, Fontan AC. 2003. Flow variability near the Cape Verde frontal zone (subtropical Atlantic Ocean). Oceanologica Acta 26(2):149-59.

Wooster WS, Bakun A, McLain DR. 1976. The seasonal upwelling cycle along the eastern boundary of the North Atlantic. Journal of Marine Research 34(2): $131-41$.

Zenk W, Klein B, Schroder M. 1991. Cape Verde frontal zone. Deep-Sea Research 38(S1):505-30. 